University of Nebraska - Lincoln

DigitalCommons@University of Nebraska - Lincoln

Faculty Papers and Publications in Animal

Science

Animal Science Department

January 1980

\title{
ADJUSTMENT OF 21-DAY LITTER WEIGHT FOR NUMBER OF PIGS NURSED FOR PUREBRED AND CROSSBRED DAMS
}

\author{
E. R. Wilson \\ Oklahoma Agricultural Experiment Station, Stillwater \\ R. K. Johnson \\ University of Nebraska-Lincoln, rjohnson5@unl.edu
}

Follow this and additional works at: https://digitalcommons.unl.edu/animalscifacpub

Part of the Animal Sciences Commons

Wilson, E. R. and Johnson, R. K., "ADJUSTMENT OF 21-DAY LITTER WEIGHT FOR NUMBER OF PIGS NURSED FOR PUREBRED AND CROSSBRED DAMS" (1980). Faculty Papers and Publications in Animal Science. 16.

https://digitalcommons.unl.edu/animalscifacpub/16

This Article is brought to you for free and open access by the Animal Science Department at DigitalCommons@University of Nebraska - Lincoln. It has been accepted for inclusion in Faculty Papers and Publications in Animal Science by an authorized administrator of DigitalCommons@University of Nebraska - Lincoln. 


\title{
ADJUSTMENT OF 21-DAY LITTER WEIGHT FOR NUMBER OF PIGS NURSED FOR PUREBRED AND CROSSBRED DAMS ${ }^{1}$
}

\author{
E. R. Wilson ${ }^{2}$ and R. K. Johnson ${ }^{3}$ \\ Oklaboma Agricultural Experiment Station, Stillwater 74074
}

\section{Summary}

Litter data from two crossbreeding experiments were used to estimate coefficients for regressing 21-day litter weight on litter size at 21-days. Exp. 1 involved 1,003 purebred and $F_{1}$ gilts of Hampshire, Duroc and Yorkshire breeding and 206 second parity sows of Duroc, Hampshire and Yorkshire breeding; Exp. 2 involved $388 \quad F_{1}$ gilts and sows of Duroc, Yorkshire, Landrace and Spot breeding. The linear and quadratic regression coefficients from the gilt data in Exp. 1 were $5.64 \pm .29$ $\mathrm{kg} / \mathrm{pig}$ and $-.10 \pm .02 \mathrm{~kg} /(\mathrm{pig})^{2}$, respectively. For Exp. 2, the regression coefficients were $5.98 \pm .71 \mathrm{~kg} / \mathrm{pig}$ and $-.14 \pm .05 \mathrm{~kg} /(\mathrm{pig})^{2}$. In both data sets, there was less than a $.5 \%$ reduction in $\mathbf{r}^{2}$ when the model was reduced from a linear and quadratic to a linear equation. The linear regression coefficients were $4.28 \pm .07$ $\mathrm{kg} / \mathrm{pig}$ and $3.91 \pm .14 \mathrm{~kg} / \mathrm{pig}$ in Exp. 1 and 2, respectively. The linear and quadratic regression coefficients from sow data in Exp. 1 were 6.28 $\pm .55 \mathrm{~kg} / \mathrm{pig}$ and $-.14 \pm .04 \mathrm{~kg} /(\mathrm{pig})^{2}$. When the model was reduced to a linear model, there was a significant interaction between breed of dam and the linear regression coefficient. These regression coefficients were $4.74 \pm .25 \mathrm{~kg} / \mathrm{pig}$ for Duroc, $4.73 \pm .26 \mathrm{~kg} / \mathrm{pig}$ for Hampshire and $3.55 \pm .30 \mathrm{~kg} / \mathrm{pig}$ for Yorkshire. Breed of dam differences for gilt 21-day litter weight adjusted to constant litter size were significant in Exp. 1. Duroc dam litters weighed less than litters of Hampshire, Yorkshire and the $F_{1}$ crosses. In Exp. 2, breed of dam differences were not significant for $F_{1}$ crossbred females of Duroc, Yorkshire, Landrace and Spot breeding, and

\footnotetext{
'Journal Article 3692 of the Agr. Exp. Sta., Oklahoma State Univ., Stillwater. Research was carried out in cooperation with USDA, SEA, Southern Region.

${ }^{2}$ KLEEN-LEEN INC,, 2720 First Ave. N.E., Cedar Rapids, IA 52402.

${ }^{3}$ Dept. of Anim. Sci., Univ. of Nebraska, Lincoln 68503.
}

litters from second parity sows weighed $7.37 \pm$ $.71 \mathrm{~kg}$ more than gilt litters when adjusted to a constant litter size.

(Key Words: Litter Weight, Crossbred Pigs, Purebred Pigs.)

\section{Introduction}

Swine breeders and commercial producers are showing increased awareness of the need to improve sow productivity. An integral part of sow productivity is milk production, and 21-day litter weight is commonly used as its measure. Swiger and Irwin (1977) presented a selection index to improve sow productivity based on the number of pigs born alive and on 21-day litter weight. In most cases, litters have different numbers of pigs nursing to 21 days and there is a need to correct 21-day litter weight for number of pigs nursed. Swiger and Irwin (1977) proposed correction factors of $4.04 \mathrm{~kg} / \mathrm{pig}$ for gilts and $4.63 \mathrm{~kg} / \mathrm{pig}$ for sows, values which they derived from data on purebred Duroc females. Researchers have not analyzed other breeds and crossbred populations to determine whether there should be different correction factors for each breed or cross.

The objective of this study was to examine the relationship between 21-day litter weight and number of pigs at $\mathbf{2 1}$ days in purebred gilts of Duroc, Hampshire and Yorkshire breeding; in the $F_{1}$ crosses of these breeds; in purebred Duroc, Hampshire and Yorkshire sows and in $F_{1}$ gilts and sows of Duroc, Yorkshire, Landrace and Spot breeding.

\section{Materials and Methods}

Data were obtained from two Oklahoma Experiment Station crossbreeding projects conducted at the Southwestern Livestock and Forage Research Station, El Reno. The first data set consisted of information on 1,206 females of Duroc, Hampshire, Yorkshire, Duroc-Hampshire, Duroc-Yorkshire and Hampshire-Yorkshire breeding. The purebred females 
produced either purebred or crossbred offspring, while the crossbred females produced either three-breed or backcross offspring. Detailed management procedures and analyses of the crossbreeding results have been published by Young et al. (1976), Johnson et al. (1978) and Wilson and Johnson (1980). Litters in this data set were farrowed in either the spring or fall from 1971 through the spring of 1977 , except during the spring of 1974. The data from Exp. 1 were divided into two subsets, one consisting of gilt records for purebred and crossbred females and the other of records for second parity Duroc, Hampshire and Yorkshire sows. The data were separated because about one-half of the purebred sows farrowed in one season with no gilts farrowing and there were no crossbred sows in seasons when crossbred gilts farrowed.

The second experiment was conducted with $388 F_{1}$ gilts and sows of Duroc, Yorkshire,
Landrace and Spot breeding which are part of an extensive project evaluating three- and four-breed cross pigs. Records of farrowings from fall 1977 through spring 1979 were included in the analyses. The $F_{1}$ females were produced at the Stillwater swine farm from purebred herds of Duroc, Yorkshire, Landrace and Spot pigs. The Duroc and Yorkshire herds had been maintained since 1969 with the addition of at least two new sires per year. Landrace and Spot males and females were purchased in 1976 from purebred herds throughout the United States as representative samples of those breeds. These herds have been maintained since then, with at least two new sires added per year. The purebred males and females were mated to produce all possible purebred and crossbred groups. The crossbred gilts from these litters were mated to purebred or crossbred boars to produce three- or four-breed offspring.

TABLE 1. NUMBER OF LITTERS FOR EACH DAM BREED, MEAN NUMBER OF PIGS AND LITTER WEIGHT AT 21 DAYS

\begin{tabular}{|c|c|c|c|}
\hline Item & $\begin{array}{l}\text { No. } \\
\text { litters }\end{array}$ & $\begin{array}{l}\text { No. } \\
\text { pigs }\end{array}$ & $\begin{array}{l}\text { Litter } \\
\text { weight, } \mathrm{kg}\end{array}$ \\
\hline \multicolumn{4}{|l|}{ Exp. 1} \\
\hline \multicolumn{4}{|l|}{ Gilts } \\
\hline Duroc $^{\mathbf{a}}$ & 151 & 6.52 & 29.40 \\
\hline Hampshire & 153 & 6.38 & 35.77 \\
\hline Yorkshire & 137 & 7.66 & 37.14 \\
\hline DH & 195 & 7.95 & 38.35 \\
\hline DY & 183 & 7.83 & 35.09 \\
\hline HY & 184 & 7.99 & 37.56 \\
\hline \multicolumn{4}{|l|}{ Sows } \\
\hline Duroc $^{a}$ & 71 & 7.07 & 34.90 \\
\hline Hampshire & 76 & 6.66 & 35.78 \\
\hline Yorkshire & 59 & 8.29 & 43.42 \\
\hline \multicolumn{4}{|l|}{ Exp. 2} \\
\hline \multicolumn{4}{|l|}{ Gilts } \\
\hline DYa & 43 & 7.65 & 36.61 \\
\hline DL & 44 & 7.77 & 38.36 \\
\hline DS & 42 & 7.26 & 35.21 \\
\hline YL & 41 & 8.51 & 40.99 \\
\hline YS & 42 & 6.95 & 32.70 \\
\hline LS & 47 & 7.64 & 38.04 \\
\hline \multicolumn{4}{|l|}{ Sows } \\
\hline DYa & 20 & 8.15 & 48.46 \\
\hline DL & 25 & 8.76 & 48.22 \\
\hline DS & 18 & 7.56 & 44.88 \\
\hline YL & 23 & 8.70 & 49.07 \\
\hline YS & 23 & 8.13 & 38.04 \\
\hline LS & 20 & 7.95 & 47.23 \\
\hline
\end{tabular}

${ }^{\mathrm{a}} \mathrm{D}=$ Duroc, $\mathrm{H}=$ Hampshire, $\mathrm{Y}=$ Yorkshire, $\mathrm{L}=$ Landrace, $\mathrm{S}=$ Spot $; \mathrm{DH}, \mathrm{DY}$, etc. represent combined reciprocally-crossed females of the breeds. 
TABLE 2. ANALYSES OF VARIANCE OF 21-DAY LITTER WEIGHT FOR GILTS FROM EXP. 1

\begin{tabular}{|c|c|c|c|c|c|c|}
\hline Source & df & $\begin{array}{l}\text { Model IV } \\
\text { MS }\end{array}$ & $\mathrm{df}$ & $\begin{array}{l}\text { Model III } \\
\text { MS }\end{array}$ & $\mathrm{d} \mathbf{f}$ & $\begin{array}{l}\text { Model II } \\
\text { MS }\end{array}$ \\
\hline Season & 11 & $369.44 * * *$ & 11 & $379.71 * * *$ & 11 & $383.69 * * *$ \\
\hline Bod $^{a}$ & 5 & 14.93 & 5 & $316.70^{* * *}$ & 5 & $319.15^{* * *}$ \\
\hline No. 21 day & 1 & $10,530.74^{* * *}$ & 1 & $12,417.79^{* * *}$ & 1 & $109,207.03^{* * *}$ \\
\hline$(\text { No. } 21 \text { day })^{2}$ & 1 & $635.08^{* * *}$ & 1 & $769.16^{* * *}$ & & \\
\hline Bod $X$ no. 21 day & 5 & 40.07 & & & & \\
\hline Bod $X$ (no. 21 day $)^{2}$ & 5 & 41.59 & & & & \\
\hline \multirow[t]{2}{*}{ Residual } & 974 & 31.63 & 984 & 31.65 & 985 & 32.40 \\
\hline & & 81.06 & & 80.86 & & 80.39 \\
\hline
\end{tabular}

a Breed of dam.

$* * * P<.001$

The number of pigs at 21 days and 21-day litter weight were considered as traits of the dam, and the breed of sire of the litter was ignored. Table 1 gives the number of females, mean number of pigs and mean litter weight at 21 days for each breed group.

The management procedures from farrowing until 21 days were similar for the two experiments. Females were moved to a central farrowing house approximately 2 days before farrowing. Each sow was placed in a farrowing crate equipped with partially slotted floors and remained there up to 1 week after farrowing. Sows were then moved to nursery facilities and placed in concrete pens which housed individual litters. Each sow was allowed to raise the pigs that she farrowed and no pigs were transferered among sows. All pigs were weighed at $21 \pm 1$ days, and their weights were adjusted to a 21-day weight. Creep feed was not placed in the pens until after the 21-day weight had been recorded.

Statistical analyses were similar for all three sets of data. The initial model (Model IV) included effects for year-season, breed of dam, linear and quadratic effects of number of pigs and the interactions of breed of dam with linear and quadratic effects. All factors were considered to be fixed. Model III was a reduced model which included effects for year-season, breed of dam and linear and quadratic partial regressions. Model II included the effects of year-season, breed of dam and linear partial regression coefficient. Models used for the third data set (Exp. 2) also included an effect for parity.

\section{Results}

Analyses of Variance. Analyses of variance for gilt and sow data from Exp. 1 are presented

TABLE 3. ANALYSES OF VARIANCE OF 21-DAY LITTER WEIGHTS FOR SOWS FROM EXP. 1

\begin{tabular}{|c|c|c|c|c|c|c|c|}
\hline Source & df & $\begin{array}{l}\text { Model IV } \\
\text { MS }\end{array}$ & df & $\begin{array}{l}\text { Model III } \\
\text { MS }\end{array}$ & Source & df & $\begin{array}{l}\text { Model I } \\
\text { MS }\end{array}$ \\
\hline Season & 3 & $87.82 * * *$ & 3 & 85.64 & Season & 3 & 81.40 \\
\hline Bod $^{\mathrm{a}}$ & 2 & 5.15 & 2 & $198.23 * * *$ & Bod & 2 & $263.75^{* * *}$ \\
\hline No. pigs & 1 & $3,135.64 * * *$ & 1 & $4,405.92^{* * *}$ & No. pigs (Bod) & 3 & $8,934.29 * * *$ \\
\hline$(\text { No. pigs) })^{2}$ & 1 & $220.74^{* * *}$ & 1 & $423.53^{* * *}$ & Residual & 197 & 33.48 \\
\hline Bod $X$ no. pigs & 2 & 33.98 & & & & & \\
\hline Bod $\times$ (no. pigs $)^{2}$ & 2 & 75.04 & & & & & \\
\hline Residual & 194 & 32.08 & 198 & 33.12 & & & \\
\hline$r^{2}$ & & 84.02 & & 83.16 & & & 83.07 \\
\hline
\end{tabular}

\footnotetext{
${ }^{\mathrm{a}}$ Breed of dam
}

$* *$ * $<.001$. 
in tables 2 and 3. The interactions between breed of dam and the linear and quadratic partial regressions for data set 1 were small and nonsignificant (table 2). Therefore, the model that best fits the data for gilts of Duroc, Hampshire, Yorkshire and $F_{1}$ crosses is one which includes the partial linear and quadratic regression coefficients. Although the partial quadratic regression coefficient was highly significant, deleting it from the model reduced the $\mathrm{r}^{2}$ by less than .5\% (table 2). The interaction of breed of dam with the partial linear regression coefficient was not significant.

The analyses of variance for data of sows of Duroc, Hampshire and Yorkshire breeding (table 3 ) revealed no significant interaction between breed of dam and the linear and quadratic partial regression coefficients. However, when the quadratic coefficient was deleted, there was an interaction between breed of dam and the linear partial regression coefficient; therefore, linear regression coefficients should be calculated within each breed of dam. When partial linear regression coefficients were fitted for each breed, $\mathrm{r}^{2}$ was reduced by less than $.1 \%$ below the value obtained with the model that included partial linear and quadratic regression coefficients pooled over breeds.

The models used for analysis of data from Exp. 2 included an effect for parity in addition to the effects incorporated into the basic models described earlier. The interactions between parity and the linear and quadratic partial regression coefficients were essentially zero (table 4). Initially, gilt and sow data were analyzed separately, and the difference between the linear coefficients was less than $.05 \mathrm{~kg}$, providing little evidence of an interaction between parity and the linear coefficient. There was little evidence of an interaction between type of crossbred dam and the partial regression coefficients, so the model was simplified. As was the case for gilts in Exp. 1, the quadratic partial regression coefficient was significant, but there was a reduction of only $.5 \%$ in the $r^{2}$ when the quadratic term was deleted from the model.

Regression Coefficients. The partial linear and quadratic regression coefficients were similar for all data (table 5). Vangen (1974) studied litters from Norwegian Landrace females and estimated the first and second degree polynomials. The linear coefficients were similar to those obtained in the present study; however, the quadratic coefficients were

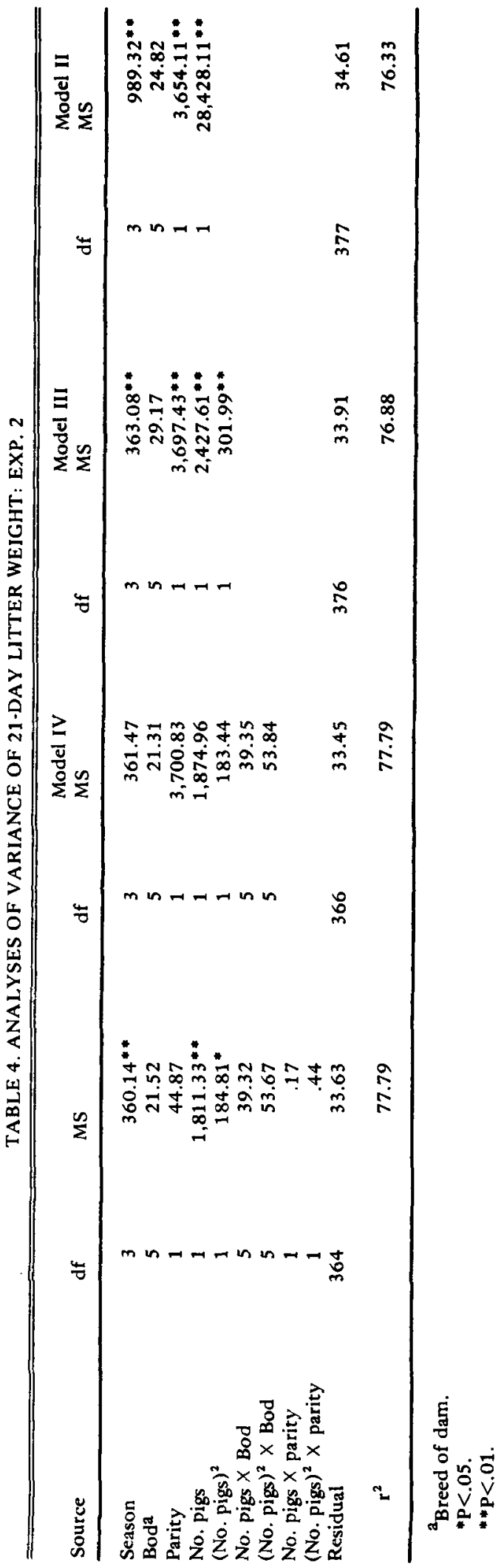


TABLE 5. PARTIAL REGRESSION COEFFICIENTS FOR 21-DAY LITTER WEIGHT REGRESSED ON NUMBER OF PIGS FROM THREE DATA SETS

\begin{tabular}{lrrr}
\hline Item & Model & Linear & Quadratic \\
\hline Exp. 1 & III & $5.64 \pm .29$ & $-.10 \pm .02$ \\
$\quad$ Duroc, Hampshire, & II & $4.28 \pm .07$ & $-.14 \pm .04$ \\
Yorkshire and F, gilts & III & $6.28 \pm .55$ & $-.14 \pm .05$ \\
Duroc, Hampshire and Yorkshire sows & & & $5.98 \pm .71$ \\
Exp. 2 & III & $3.91 \pm .14$ & \\
Duroc, Yorkshire, Landrace and Spot & II & & \\
F, gilts and sows & &
\end{tabular}

larger negative values. The difference may have been due to differences in litter size; Vangen included litters with up to 22 pigs, while in the present study only one litter was larger than 14 pigs at 21 days.

Since there was less than a $.5 \%$ reduction in the $r^{2}$ when the model was reduced from a linear and quadratic to a linear model for all data sets, it would appear that the linear partial regression coefficient would give a practical adjustment for 21-day litter weight for number of pigs at 21 days. The value of $4.28 \pm .07$ $\mathrm{kg} / \mathrm{pig}$ obtained with purebred and crossbred gilts in Exp. 1 was larger than the $3.91 \pm .14$ $\mathrm{kg} / \mathrm{pig}$ value from crossbred gilts and sows in Exp. 2. Swiger and Irwin (1977) estimated the linear coefficient to be $4.04 \mathrm{~kg} / \mathrm{pig}$ for Duroc gilts and $4.63 \mathrm{~kg} /$ pig for Duroc sows. Korkman (1947) reported a linear regression coefficient of $3.74 \mathrm{~kg} / \mathrm{pig}$ in Landrace and Large White sows.

The linear regression coefficients for Duroc and Hampshire sows were similar, and both were greater than the linear coefficient for Yorkshire sows (table 6). This finding suggests that linear regression coefficients for sows of Duroc, Hampshire and Yorkshire may be breed dependent.

Within-breed regressions were also calculated for gilts in Exp. 1, although the interaction was not significant. Duroc, Hampshire and Yorkshire gilts had linear regression coefficients of $4.33 \pm .18,4.60 \pm .19$ and $4.35 \pm .18 \mathrm{~kg} / \mathrm{pig}$, respectively, and $F_{1}$ Duroc-Hampshire, DurocYorkshire and Hampshire-Yorkshire gilts had coefficients of $4.45 \pm .19,4.05 \pm .16$ and 4.03 $\pm .18 \mathrm{~kg} / \mathrm{pig}$, respectively.

The effect of parity on 21-day litter weight was estimated from data from Exp. 2. There was little evidence for the use of different regression coefficients for sows and gilts. Second parity sows had litters that were $7.37 \pm$ $.71 \mathrm{~kg}$ heavier than those of gilts when adjusted for number of pigs in the litter. This difference was similar to that reported by Vangen (1974) and Swiger and Irwin (1977).

Duroc, Hampshire, Duroc-Yorkshire (DY), Duroc-Hampshire (DH) and Hampshire-Yorkshire (HY) dam groups were compared to Yorkshire for 21-day litter weight adjusted for litter size (table 7). The differences between breed groups were similar when calculated from the pooled regression coefficients of either the curvilinear or linear equations. At a constant litter size, litters from Duroc gilts were $2.67 \pm$ $.68 \mathrm{~kg}$ lighter than Yorkshire litters. Hampshire, DH and HY litters tended to be heavier than Yorkshire litters while DY litters tended to be lighter. If comparisons were made between Duroc, Yorkshire and Hampshire second parity sows, the difference between breeds would depend on the litter size at which the comparison was made, because adjustment factors were different for each breed. If the objective was to compare milk production of different breeds, these data indicate, 21-day litter weight

TABLE 6. SOW BREED LINEAR REGRESSION COEFFICIENTS FOR 21-DAY LITTER WEIGHT REGRESSED ON LITTER SIZE AT 21 DAYS

\begin{tabular}{ll}
$\begin{array}{l}\text { Breed } \\
\text { of sow }\end{array}$ & Linear \\
\hline Duroc & $4.74 \pm .25^{* * *}$ \\
Hampshire & $4.73 \pm .26^{* * *}$ \\
Yorkshire & $3.55 \pm .30^{* * *}$ \\
\hline
\end{tabular}

$* * \mathrm{P}<.001$. 
TABLE 7. COMPARISON OF DUROC, HAMPSHIRE, YORKSHIRE AND F, GILTS FOR 21-DAY LITTER WEIGHT ADJUSTED TO A CONSTANT LITTER SIZE

\begin{tabular}{lcc}
\hline Contrast & Model III & Model II \\
\hline D-Ya & $-2.84 \pm .67^{*}$ & $-2.67 \pm .68^{*}$ \\
DH-Y & $1.40 \pm .80$ & $1.45 \pm .81$ \\
DY-Y & $-.83 \pm .81$ & $-.94 \pm .82$ \\
H-Y & $.37 \pm .67$ & $.57 \pm .68$ \\
HY-Y & $.87 \pm .81$ & $.82 \pm .82$ \\
\hline
\end{tabular}

\footnotetext{
${ }^{\mathbf{a}} \mathrm{D}=$ Duroc, $\mathrm{H}=$ Hampshire, $\mathrm{Y}=$ Yorkshire. $\mathrm{DY}$ represents reciprocal females of Duroc and Yorkshire breeding.

$* \mathrm{P}<.05$.
}

would have to be adjusted to a constant litter size with within-breed corrction factors. Comparison of unadjusted breed means might also be useful, but this would involve the joint effects of numbers of pigs and milk production. Since the analyses of variance for the $F_{1}$ crossbred sows and gilts of Duroc, Yorkshire, Landrace and Spot breeding gave little evidence of a significant breed of dam effect (table 4), no comparisons among the six crossbred dam types are given.

These data suggest that when 21-day litter weight is adjusted for number of pigs, different corrections may be needed for purebred and crossbred females. The estimate of the linear regression coefficient from the Duroc, Hampshire and Yorkshire data (Exp. 1) was larger than the value of $4.08 \mathrm{~kg} / \mathrm{pig}$ recommended by Swiger and Irwin (1977), while the regression coefficient of $3.91 \pm .14$ from crossbred fe- males of Duroc, Yorkshire, Landrace and Spot breeding (Exp. 2) was slightly smaller. The regression coefficient for gilts given by Swiger and Irwin (1977) was approximately the mean value of the linear regression coefficients obtained in this paper. Indications are that Yorkshire sows need a correction factor different from that for Duroc or Hampshire sows and that there is an interaction between parity and the change in litter weight for each pig nursed in the Yorkshire breed. Breed of dam and parity effects are important for 21-day litter weight. Most useful comparisons among females can be made if carried out within breed of dam and adjusted for parity and number of pigs nursed.

\section{Literature Cited}

Johnson, R. K., I. T. Omtvedt and L. E. Walters. 1978. Comparison of productivity and performance for two-breed and three-breed crosses in swine. J. Anim. Sci. 46:69.

Korkman, N. 1947. Causes of variation in the size and weight of litters from sows. Acta Agr. Scand. $2: 253$.

Swiger, L. A. and K. M. Irvin. 1977. Selecting for sow productivity. Proc. National Swine Improvement Federation Convention and Annu. Meet., St. Louis, MO.

Vangen, Odd. 1974. Preweaning weights in lines of pigs selected for rate of gain and thickness of backfat. Acta Agr. Scand. 24:195.

Wilson, E. R. and R. K. Johnson. 1980. Comparison of three-breed and backcross swine for litter productivity and postweaning performance. J. Anim. Sci. (Submitted).

Young, L. D., R. K. Johnson and I. T. Omtvedt. 1976. Reproductive performance of swine bred to produce purebred and two-breed cross litters. J. Anim. Sci. 42:1133. 